\title{
Two Private Prayers in Wall Inscriptions in the Faras Cathedral
}

\author{
AdAM ŁaJTAR, GRZEGORZ OCHAŁA
}

\begin{abstract}
The present paper aims at analysing two inscriptions from the Faras Cathedral. Both contain prayers addressed to God by certain individuals. The first of them is in Greek and is modelled on Ps. 85:1-2; the second is an original composition in Old Nubian with information about the protagonist and the author in Greek. The publication gives the description of inscriptions, transcript of texts with critical apparatus, translation, and commentary elucidating all significant aspects of the texts.
\end{abstract}

Keywords: Christian Nubia, Faras, wall inscriptions, Greek in Christian Nubia, Old Nubian, Biblical citations

Adam Łajtar, Institute of Archaeology, University of Warsaw, Warszawa; a.f.lajtar@uw.edu.pl

Grzegorz Ochała, Institute of Archaeology, University of Warsaw, Warszawa; g.ochala@uw.edu.pl

The present article has come into existence in connection with our work on a catalogue of wall inscriptions in the Faras cathedral. ${ }^{1}$ It offers the publication of two inscriptions, which, although they differ from one another in many respects (a different location within the sacral space, a different technique of execution, and a different language), belong to the same genre of texts, namely prayers addressed to God by individuals.

A typical private prayer put into an epigraphic text in Christian Nubia consists of two elements: (1) an invocation of God or a saint, and (2) a request for a favour made in the name of a person. The inscriptions studied here follow this general model but develop it in a different way with respect to both the form and the contents.

\section{PRAYER FOR KINYAKOUDA(?)}

The inscription was situated on the west wall of the north pastophorium (Fig. 1). It measured $7 \mathrm{~cm}$ in width and $3.5 \mathrm{~cm}$ in height. It was executed in black ink. It bears number G.60d.2/3

\footnotetext{
${ }^{1}$ For a short presentation of the project and its first results, see: Łajtar, Ochała 2015.
} 


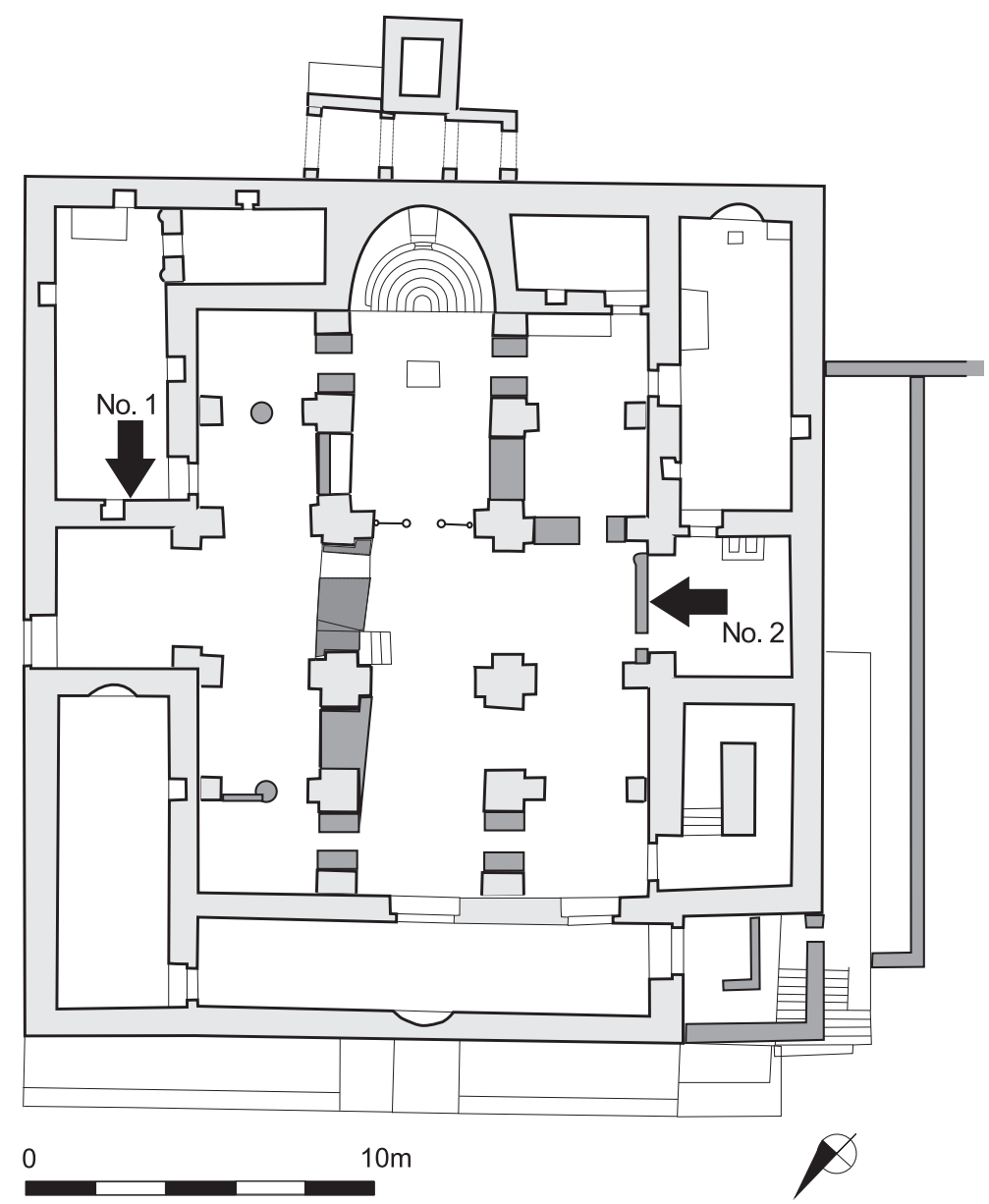

1. Plan of the Faras cathedral with location of the inscriptions marked with arrows (Digitizing: D. Zielińska; based on: Godlewski 2006: Fig. 5).

in Stefan Jakobielski's inventory of inscriptions prepared during the 1962/1963 season of work by the Polish mission in Faras. It was left on site and is now lost under the waters of Lake Nubia. The inscription was written on the second and the last layer of plaster covering the wall in this place, which means that it can be only broadly dated to the tenth-fifteenth century. ${ }^{2}$

The inscription remains unpublished. It was not edited by Jadwiga Kubińska in her study devoted to the north pastophorium of the Faras cathedral. ${ }^{3}$ Kubińska noted only, after Jakobielski's inventory files, that the inscription consisted of five lines in Old Nubian, ${ }^{4}$

\footnotetext{
2 The second layer of plaster was connected with the rebuilding of the cathedral during the episcopate of Bishop Petros I (AD 976-999); for this rebuilding, see: Godlewski 2006: 93-117.

3 Kubińska 1976.

${ }^{4}$ Kubińska 1976: 34 (no. 59).
} 
2. Inscription no. 1 (C IKŚiO PAN).

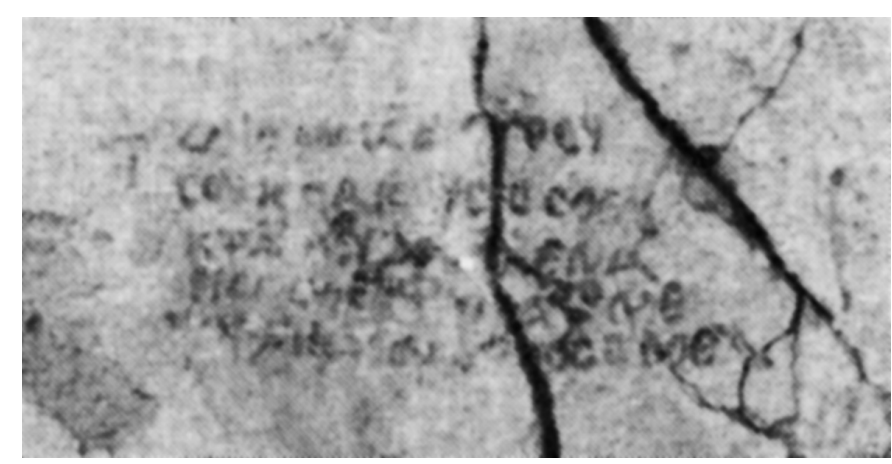

a note which has been proven false by the present edition. Our edition was prepared mainly on the basis of Jakobielski's transcript kept in the inventory files. The photo was of less importance as it is very blurred (Fig. 2).

$$
\begin{aligned}
& \dagger \kappa \lambda i ̂ v o v, \kappa(v ́ \rho \imath) \varepsilon, \tau o ̀ ~ o v ̉ ~
\end{aligned}
$$

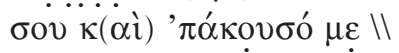

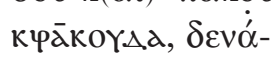

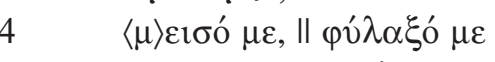

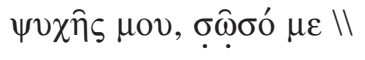

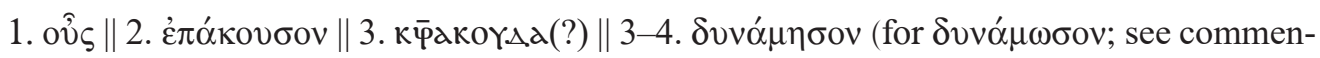
tary) \| 4. $\varphi \hat{\lambda} \lambda \alpha \xi_{\text {ov }} \| 5 . \sigma \omega \hat{\sigma} \sigma o v$

Bow down Thine ear, O Lord, and hear me, Kinyakouda(?), strengthen me, guard my soul, save me.

The inscription is composed as a prayer in the name of a certain Kinyakouda. The prayer

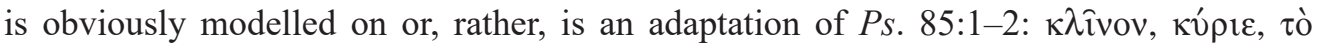

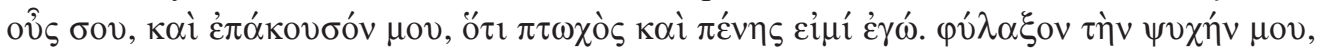

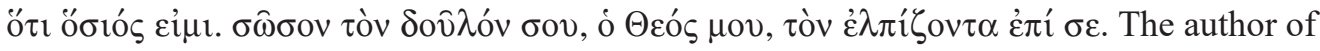
the prayer (Kinyakouda or someone commissioned by him) kept some expressions of the

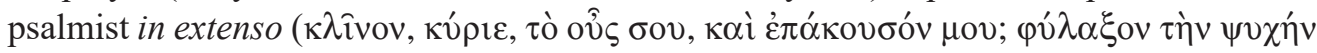

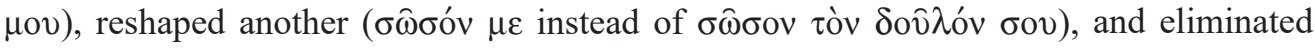

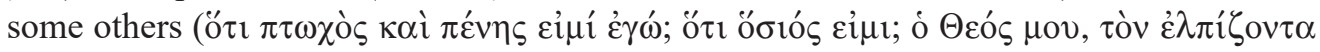
$\dot{\varepsilon} \pi \dot{i} \sigma \varepsilon)$. It is easy to observe that the retained expressions are those containing verbs of request, whereas the eliminated one refers to the requesting person and characterises his/her attitude towards God. In addition, the author used one more verb of request that

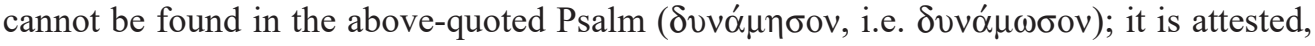
however, elsewhere in the Book of Psalms, in Ps. 67:29.

The inscription shows numerous graphic peculiarities. The most characteristic of them is dropping the final $\mathrm{N}$ in forms of the aorist imperative before the following 


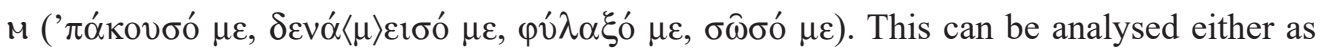
a phonetic notation of the aorist imperative forms under the loss of $/ \mathrm{n} /$ at the end of the word, a phenomenon frequently occurring in post-Classical Greek, ${ }^{5}$ or as an example of assimilation of $/ \mathrm{n} /$ and $/ \mathrm{m} /$ with the concomitant haplography: /phylaxonme/ > /phylaxomme/ > phylaxome $/ .{ }^{6}$ One needs to note that the two possibilities may have overlapped. A somewhat similar situation can be observed in the phrase ov $\sigma o v$ (11. 1-2), where the omission of the c may result from either haplography or the loss of /s/ in final position, which, in late Greek, is as common as that of $/ \mathrm{n} / .^{7}$ The occurrence of $\psi v \chi \bar{\eta} \varsigma$ instead of $\psi v \chi \eta \dot{\eta} v$ in line 5 may be caused by the same phenomena too: the loss of $/ \mathrm{n} / \mathrm{in}$ final position with the concomitant insertion of $/ \mathrm{s} /$. Additionally, one observes an unorthodox

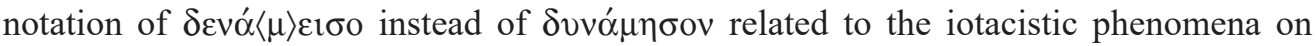
the one hand and the substitution of $\epsilon / \mathrm{e} /$ for $\gamma / \mathrm{i} /$ on the other, the latter being a rather rare phenomenon rooted in the pronunciation of post-Classical Greek. For other, more specific phenomena, see the line commentary.

An interesting element of the inscription is the use of a double stroke as an editorial sign. In line 2 the double oblique stroke seems to mark the end of a colon and in line 4 the vertical double stroke probably indicates the end of the first verse of the Psalm, even if the verse was considerably reshaped in comparison with the original. The oblique double stroke at the end of line 5 marks the end of the inscription and the end of the second verse of the Psalm (again considerably changed in comparison with the original). ${ }^{8}$

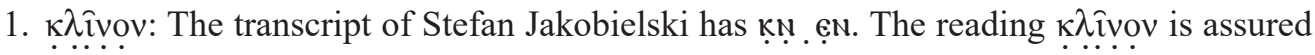
by the textual parallel (see above).

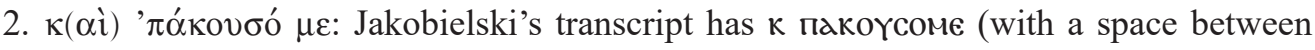
$\kappa$ and $\pi)$. We have edited the text as if we were dealing with the abbreviation for $\kappa \alpha$ í (pronounced $/ \mathrm{ke} /$ ) and apheresis. ${ }^{9}$ Another possibility is to admit a kind of haplography and

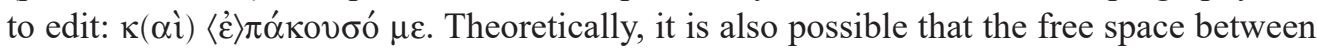
$\kappa$ and $\pi$ originally contained the letter $\epsilon$ (now lost), which would give the reading $\kappa(\alpha i)$

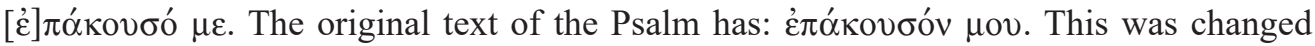

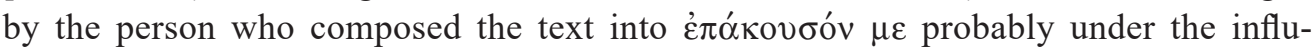
ence of other aorist imperatives with $\mu \varepsilon$ as a direct object occurring in it. An additional factor contributing to this change could have been the collapse of the Greek system

\footnotetext{
5 Gignac 1976: 111-114.

${ }^{6}$ Such a phenomenon (assimilation + haplography) is quite common in the Old Nubian language; see, e.g., commentary to 1.3 (c)okd) in inscr. no. 2, below.

7 Gignac 1976: 124-131.

${ }^{8}$ Double vertical and oblique strokes occur frequently as diacritics in literary and subliterary texts from Christian Nubia. Their function requires a separate study.

${ }^{9}$ Apheresis is sporadically attested in Nubian Greek. The clearest example occurs in a visitor's graffito in

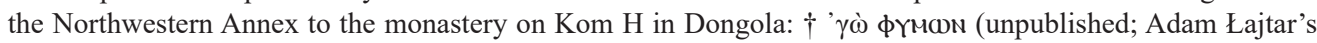
reading from the original).
} 
of declension in Christian Nubia. Inscriptions left by visitors in cult places, frequently constructed according to the pattern: 'I, NN, wrote this', show that various forms of the pronoun of the first person singular [ $\dot{\varepsilon} \gamma \omega \dot{\omega},(\dot{\varepsilon}) \mu \mathrm{ov},(\dot{\varepsilon}) \mu \dot{\varepsilon}]$ were considered, irrespective of the syntax, as just different words for the same general notion ' $I$ '. ${ }^{10}$

3. кчд̄коүАд: Stefan Jakobielski's transcript offers кчд коүАд; however, a free space between $\alpha$ and $\kappa$ is probably purely accidental. Here we are obviously dealing with a personal name. The name $к \varphi \bar{\kappa} \kappa \gamma_{\lambda} \lambda$, attested for the first time here, is puzzling. Morphologically it is a compositum with кoү $\Delta d-$, 'servant', as the second element. ${ }^{11}$ Its first element poses a problem. $\mathrm{\kappa} \varphi \mathrm{d}$ - is phonetically unlikely; one expects a horizontal stroke above $\kappa \varphi$ indicating / $\mathrm{i} / \mathrm{in}$ order for the form to be pronounced. However, even if this observation holds true, the word $\kappa \bar{\varphi} \mathrm{d}-$ has not to date been attested in Old Nubian. We know the word $\kappa \bar{\varphi}(\varphi)-$, '(to be) without', but it does not offer a satisfactory meaning in the given context. The parallel formations show that what is expected here is a name of a saint or a word referring to divinity. Under these circumstances we have to content ourselves with a non liquet.

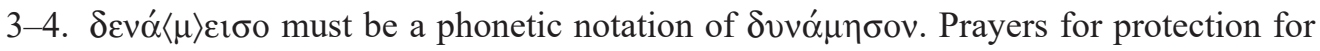
the donors accompanying painted representations in the Faras cathedral contain, among other requests, $\dot{\varepsilon} \delta \delta v \alpha \alpha \mu \eta \sigma o v$, 'strengthen!'. ${ }^{12}$ Obviously the verb $\delta v v \alpha \mu$ ó $\omega$ had the form $\delta v v \alpha \mu \varepsilon \varepsilon^{\prime} \omega$ in Faras and possibly elsewhere in Christian Nubia. ${ }^{13}$

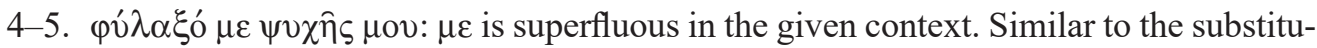
tion of $\mu \varepsilon$ for $\mu \mathrm{ov}$ in line 2 , it was probably introduced under the influence of other aorist imperatives with $\mu \varepsilon$ as the direct object occurring in this inscription.

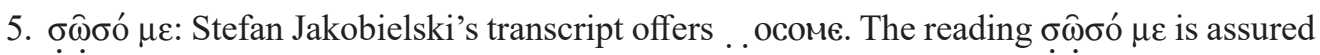
by the textual parallel (see above).

\section{PRAYER FOR ARWA}

The inscription (Fig. 3) was incised in the plaster of the walled-up arcade between the southern aisle and the southern vestibule (Fig. 1). It measured $107 \mathrm{~cm}$ in width and $28 \mathrm{~cm}$ in height. It bears number K.253a.4 in Stefan Jakobielski’s inventory of inscriptions. It was

10 Łajtar 2003: 141; 2010: 760.

11 For such names, see: Satzinger 1992.

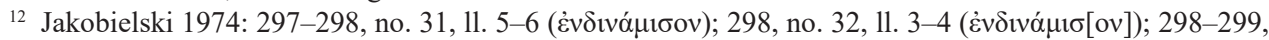

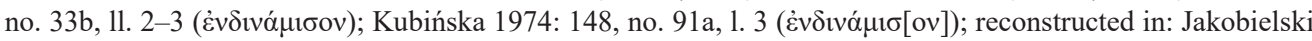

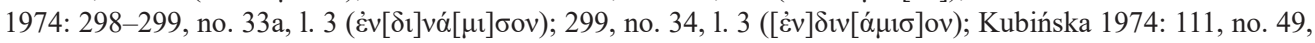

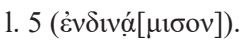

${ }^{13}$ For similar phenomena in post-classical Greek (change of the thematic vowel of contracted verbs), see: Gignac 1981: 363-365. 


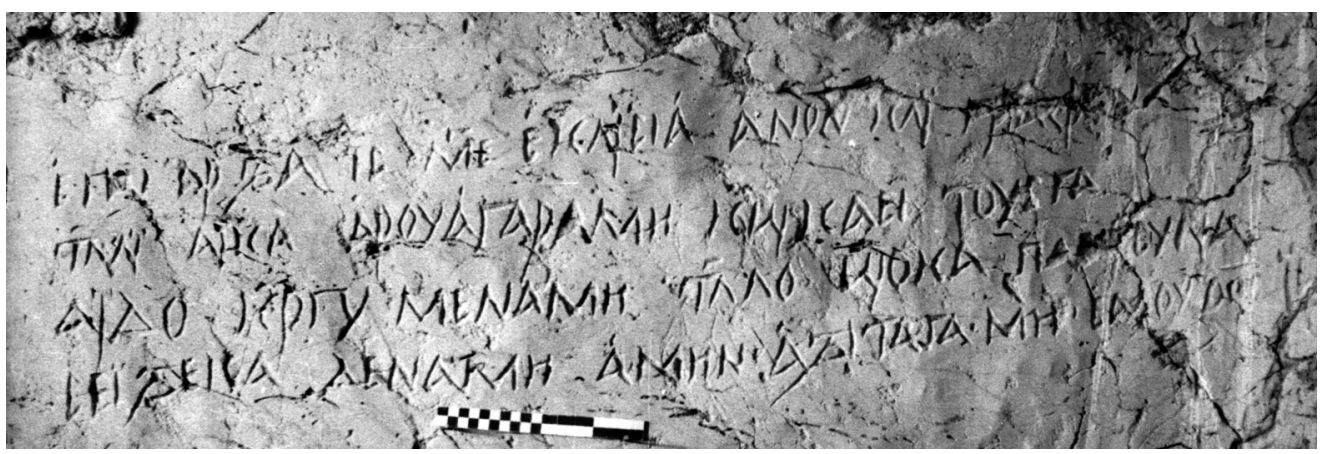

3. Inscription no. 2 (C IKŚiO PAN).

left on site and is now lost under the waters of Lake Nubia. The partition wall between the aisle and the southern vestibule came into existence during the last reconstruction of the cathedral sometime in the Late period, ${ }^{14}$ which indicates that the inscription should be dated to the twelfth century at the earliest.

The inscription was transcribed and partly analysed by Stefan Jakobielski in his seminal work about the history of the Faras bishopric. ${ }^{15}$ Jakobielski rightly recognised the name of the inscription's protagonist and his church affiliation opening the text (apकa 'I(

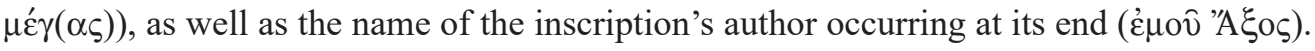
The rest was incomprehensible to him. The present edition was prepared mainly on the basis of a photograph of the inscription with the additional help of Jakobielski's transcript.

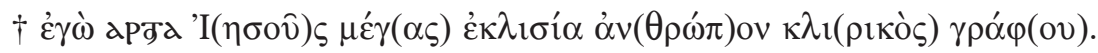

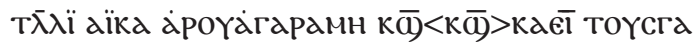

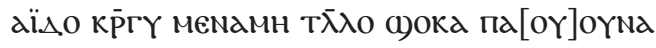

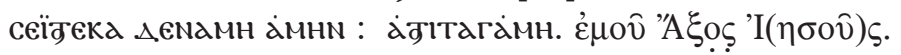

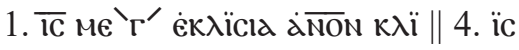

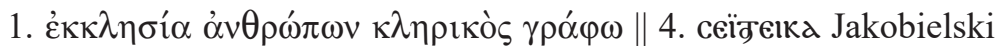

I, Arwa, cleric of the Great (Church of) Jesus of the people, write (this). Let God protect me! Do not let the jealous ones cause a curse to come upon me! Let God give the Book to the inheritor of power. Amen, let it be done. I, Axos, (of the Church of) Jesus.

The inscription starts with a presentation of its protagonist (1. 1) and closes with a subscript of its writer (end of 1. 4). These two pieces of information are in Greek. The rest of the text is in Old Nubian and contains a prayer in the name of a single individual (cf. dïka, 'me', in 1. 2), most probably the protagonist.

\footnotetext{
${ }^{14}$ For the latest modification in the cathedral, see: Godlewski 2006: 119-137, especially 123-124, with Figs 114-115 (about the partition wall between the aisle and the southern vestibule).

15 Jakobielski 1972: 172, Fig. 51.
} 
The prayer seems to consist of three requests expressed in the impersonal imperative with predicative $-\alpha$ and command suffix $-\mathrm{MH}$, which is worth stressing as the form used in this kind of texts is normally the second-person imperative. If the first request asks God quite generally for protection, the second expresses a wish that a curse on the part of jealous persons not fall upon the protagonist. By 'curse' the author probably meant any hostile action of a magical character against the protagonist, be it now or in the future, although one cannot exclude that he had in mind a specific act, even if not named. In the third request, God is asked to grant a book to a person called 'the inheritor of power'. ${ }^{16}$ It is unclear what is at stake here. The phrase 'the inheritor of power' most probably refers to the protagonist, perhaps as a member of the clergy representing God's power on earth. In this context, 'book' should probably be understood as the Holy Scripture as the conveyor of divine knowledge and power. One may also think about a book of spells giving the protagonist the power over all spirits in order to defend himself against magic hostilities or even to curse other people. The second possibility is especially tempting considering the overall protective character of the inscription.

An interesting element of the Old Nubian part of the inscription is its spelling. One comes across some unorthodox notations such as тоүсга (for тоүска), ג̇бıтагдімн

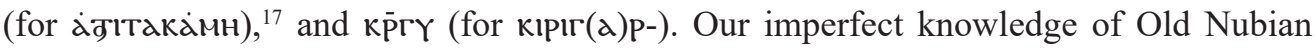
does not allow us to decide whether these unorthodox spellings are due solely to the writer or represent more general language phenomena, for example having dialectal nature.

1. The personal name Arwa (Aroua) is known mainly through the wall inscriptions in the Faras cathedral. In addition to the present inscription it is attested in inscriptions E.191c.4, E.201b.4, E.201c.4, and E.201e.4. ${ }^{18}$ All of them are visitor's inscriptions and seem to have been authored by the same person, Arwa, tot of Faras. Although his title is mentioned only in inscription E.191c.4, the palaeography of the graffiti and the fact that they were executed right next to each other, on late walls dividing the eastern part of the southern aisle, make this assumption highly probable. An epitaph from Sakinya commemorates a certain Olpna Aroua. ${ }^{19}$ The proper name apga most probably derives from the word apoY-, 'rain', and possibly also 'cover, protection', ${ }^{20}$ through the addition of the predicative $-\alpha$, hence 'the one who is protector'. It is worth noticing that the name under consideration is spelled with o here, although the verb from which it is derived is written with or in line 2.

\footnotetext{
${ }^{16}$ A series of wall inscriptions in Nubian Christian cult places including the Northwestern Annex to the monastery on Kom H at Dongola, the upper church at Banganarti, the southern pastophorium of the Faras cathedral, and the church in Medik south of Qasr Ibrim, contain a request to God to teach someone a book; for these inscriptions, see: Łajtar 2014: 266. Under 'book', the authors of these inscriptions probably understood 'book of life' in the sense 'proper way of living'.

${ }_{17}$ The change of $\kappa$ versus $\Gamma$ is very common in Old Nubian as noted by Browne 2002: 18 .

${ }_{18}$ All of them remain unpublished.

19 Mina 1942: no. 293 = Pernigotti 1975: no. 16.

${ }^{20}$ Browne 1996: 19, s.v., lemmatizes the word with only the first meaning, but the derivative verb apoүarapis attested also with the meaning 'to protect, cover'.
} 
The inscription indicates that Arwa was a cleric in a Great Church of Jesus. Interestingly enough, Axos, who wrote the inscription, also served in a church dedicated to Jesus Christ. ${ }^{21}$ Unfortunately, they did not provide any information on the location of their churches. The Great Church of Jesus is one of the most frequently (if not the most frequently) mentioned sacral edifices in the corpus of Nubian written sources, ${ }^{22}$ yet in only three instances is the exact location of the church indicated: the famous inscription from Deir Anba Hadra at $\mathrm{Aswan}^{23}$ and a commemorative inscription left by one Adelph( ) in the upper church at Banganarti ${ }^{24}$ mention a 'Great (Church of) Jesus at Timikleos (= Dongola)', ${ }^{25}$ and an anonymous visitor's graffito from the Banganarti church informs us about a 'Great (Church of) Jesus at Jagje'. ${ }^{26}$ Unless Jagje is another name for Dongola (known already as Tungul and Timikleos), we have to assume that there existed at least two Great Churches of Jesus Christ in Makuria, an assumption that hinders all guesses on the location of churches by this name, including the location

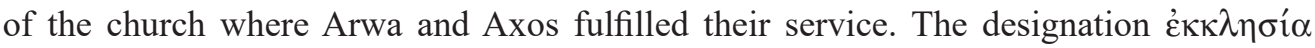
$\alpha v \theta \rho \omega ́ \pi \omega v$, literally 'church of the people' or 'people's church', is found frequently in Nubian inscriptions, especially in visitors' mementos written on the walls of cult places, in the presentation of persons. ${ }^{27}$ As far as we are aware it has not to date been attested

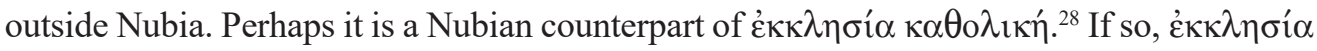
$\dot{\alpha} \theta \theta \omega \dot{\pi} \omega \nu$ would qualify a church as belonging to a bishop (in contrast to monastic or private churches).

The reading $\gamma \rho \alpha \dot{\varphi} \varphi(\mathrm{ov})$ is suggested by two other inscriptions written by Axos (see below), which attest to the use of this form. $\gamma \rho \alpha \dot{\varphi} \varphi$ p probably stands for $\gamma \rho \alpha \dot{\alpha} \varphi \omega$ through the interchange of or and $\omega$, a phenomenon frequently attested in post-classic Greek, especially in unaccented endings like here. ${ }^{29}$ It should be observed that the present tense

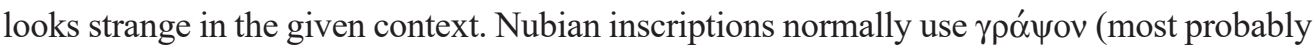
the first-person singular aorist active with the historical ending and the omission of the augment) to describe the process of leaving an inscription in a cult place.

${ }^{21}$ For the identification of Axos, see below, commentary to 1. 4, and Jakobielski 1972: 173-174.

${ }^{22}$ The attestations come from the cathedral of Faras, the upper church at Banganarti, the church of Sonqi Tino, and Deir Anba Hadra in Aswan, and are dated in the period between the tenth and the fourteenth century.

${ }^{23}$ Griffith 1928: 18-30 (no. 3), Pls 3-4. A new edition and interpretation of this text is in preparation by Adam Łajtar.

${ }^{24}$ Łajtar forthcoming: no. 960; for a translation and interpretation, see: Łajtar 2008: 399-400, Fig. 2.

${ }^{25}$ For the identification of Timikleos with the capital of Makuria, see: Łajtar 2015, complemented by Seignobos 2015. The Great Church of Jesus at Dongola should perhaps be identified with the so-called cruciform church excavated by the Polish mission at the foot of the Dongolese citadel (see: Godlewski 1990: 136).

26 Łajtar forthcoming: no. 349; mentioned in Łajtar 2006: 96 with Fig. on p. 100.

27 Examples are too numerous to be listed here. Suffice it to say that they are found in visitor's inscription on the walls of churches in Faras, Sonqi Tino, Dongola, and Banganarti.

28 This was hypothesized by Łajtar 2003: 145 with n. 15, who was the first to resolve the abbreviation aNWN as $\dot{\alpha} v(\theta \rho \omega ́ \pi) \omega v$. For the meaning of the designation $\dot{\varepsilon} \kappa \kappa \lambda \eta \sigma i ́ \alpha \kappa \alpha \theta \mathrm{o} \lambda \iota \kappa \dot{~ w i t h ~ r e l a t i o n ~ t o ~ E g y p t, ~ s e e: ~ W i p s z y c k a ~}$ 1994.

${ }^{29}$ Gignac 1976: 208-211. 
2. $T \bar{\lambda} \lambda \ddot{i}: ~ T \bar{\lambda} \lambda-$, 'God', + -i. This is a curious form, especially because the iota has a diaeresis. This makes its interpretation as a juncture vowel (or anything phonological) quite unlikely, as diaeresis indicates at least a separate syllable, and perhaps a suprasegmental value, too. Perhaps this is a variant vocative ending; cf. $T \bar{\lambda} \lambda o$ in the next line.

дроүдігарамн: дроүа்гар-, 'to rain over, cover, protect' + predicative $-\mathrm{d}+$ the marker of the imperative -мн. The form діроүагарамн is found in the so-called Griffith's Stauros-

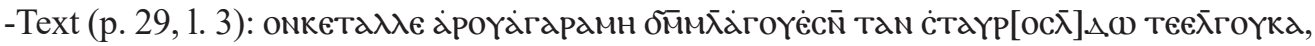
'And also let him protect all who hope in his cross'. ${ }^{30}$

$\kappa \overline{\bar{q}}<\kappa \bar{\alpha}>\kappa a \overline{\mathrm{i}}$ : The form $\kappa \overline{\bar{\alpha}} \kappa \lambda \overline{\mathrm{\epsilon}}$ standing on the wall is obviously the result of the writer's having committed a haplography by omitting one element of the reduplicated stem. The reconstructed form $\kappa \overline{\bar{\alpha}} \kappa \overline{\bar{\alpha}} \kappa \lambda \overline{\epsilon l}$ is an irregular plural of $\kappa \overline{\bar{\alpha}} \kappa \overline{\bar{\alpha}} \kappa \lambda \mathrm{TT}-$, 'envious, jealous'. ${ }^{31}$

тоүсга: This probably stands for тоүска. For the change of $\Gamma$ for $\kappa$, see also the word дंбІтагд்н in line 4 (with commentary). тоүска can be analysed as тоүс- + the accusative $-\kappa a$. The problem is that Toyc- is attested only as the verb 'to curse' and not as a substantive meaning 'curse', the latter appearing only as тоүст- in Old Nubian texts. Either the scribe made a mistake omitting a syllable, hence we should reconstruct $\operatorname{To\gamma }<<\mathrm{Tl}>\Gamma \mathrm{d}$, or Torc- could also be the substantive 'curse'.

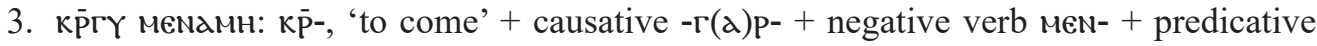
$-\mathrm{d}+$ the marker of the imperative -мн. The construction is paralleled by Адпмемнамн, 'let him not ruin', in P.QasrIbrim II 28, 1. 9; 32 see also аммемамн, 'do not say', in P.QasrIbrim II 24,1 . 15. A free space between the verb and the negation may suggest that the construc-

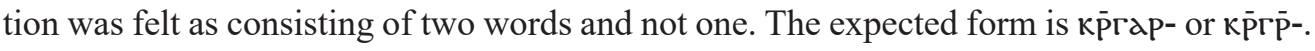
$\kappa \bar{p} \Gamma Y$ present in the inscription is a variant spelling under the loss of the final $\mathrm{p}^{33}$ and the concomitant change of the horizontal dash denoting /i/ into $Y$.

$T \bar{\lambda} \lambda \mathrm{o}: \mathrm{T} \bar{\lambda} \lambda-+$ vocative $-\mathrm{o}$. The regular vocative ending is $-\lambda$; $-\mathrm{o}$ has so far been attested only in папо, 'O father'. ${ }^{34}$

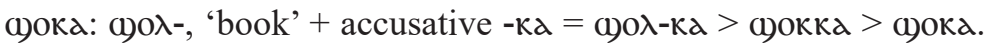

па[oY]oYnd: The reading is not entirely certain. It is possible that the first or has been lost not as a result of damage done to the plaster but through an intentional erasure made

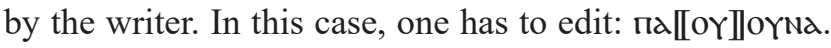

30 Browne 1983; 1989: 28 (English translation) and 29 (Old Nubian text).

31 Browne 2002: 31.

32 For the construction, see: Browne 2002: 63.

33 The loss of $\mathrm{P}$, especially after a vowel, is a frequent phenomenon in Old Nubian as noted by Browne 2002: 21-22.

34 Browne 2002: 37. 
4. ceïjeka: The verb $\Delta \mathbf{I N}^{-}$, 'to give', requires both the direct and indirect objects, both marked with the formant $-\kappa \alpha$; the latter usually follows the former. ${ }^{35}$ This means that cookd

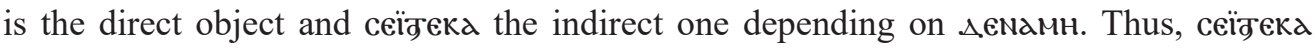

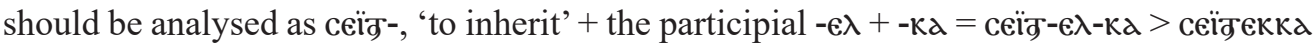
$>$ ceïंबкर.

$\triangle \in$ NaMH: $\triangle \mathrm{EN}^{-}$, 'to give' + predicative $-\mathrm{d}+$ the marker of the imperative $-\mathrm{MH}$.

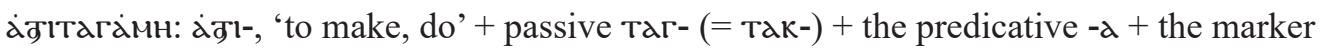
of the imperative -мн. The form means literally 'let it be done' and is obviously the Nubian

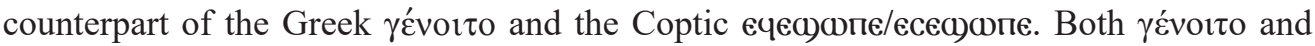

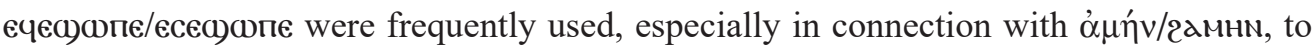
conclude prayers. Similarly, дмнн аүтакамн дімнм is found in this function at the end of Ps.-Chrysostom, In venerabilem crucem sermo (p. 25, 1. 15). ${ }^{36}$

Jakobielski's transcript has ємоҮзоc, but the photo clearly shows that a was present on the wall. Axos, who wrote this inscription, is mentioned as the scribe in another two inscriptions from Faras. One of them, containing a prayer in debased Greek, was situated immediately to the left of the text discussed here. ${ }^{37}$ The other, having the form of a typical visitor's graffito, was found in the so-called Rivergate Church at Faras. ${ }^{38}$ In the first, Axos presents himself with only his personal name. In the second, he is described as a cleric of the people's church of Jesus Christ. Apart from these three inscriptions left undoubtedly by the same man, the name Axos has not been attested in Christian Nubia. It is also unknown elsewhere in the Greek world, although it is doubtlessly of Greek origin.

\section{Acknowledgments}

The authors wish to thank Giovanni Ruffini (Fairfield University) who read through an earlier version of this paper correcting English and making useful comments about the subject. They also express their gratitude to Vincent van Gerven Oei, whose critical review of our paper considerably contributed to its improvement.

\section{References}

Browne, G.M. 1983: Griffith's Stauros-Text, StudPap 22, 75-119

Browne, G.M. 1984: Chrysostomus Nubianus: An Old Nubian Version of Ps.-Chrysostom, In venerabilem crucem sermo, PapCastr 10, Roma-Barcelona

\footnotetext{
35 Browne 2002: 35, 92.

36 Browne 1984; see also Browne 1989: 28-45 (Old Nubian text on odd pages, English translation on even pages).

37 Jakobielski 1972: 172-173, Fig. 52.

38 Griffith 1926: Pl. LXV,18; Jakobielski 1972: 173-174.
} 
Browne, G.M. 1989: Literary Texts in Old Nubian, BSF Beiheft 5, Wien-Mödling Browne, G.M. 1996: Old Nubian Dictionary, CSCO 556, Subsidia 90, Leuven Browne, G.M. 2002: Old Nubian Grammar, Languages of the World. Materials 330, Munich Gignac, F.T. 1976: A Grammar of the Greek Papyri of the Roman and Byzantine Periods I: Phonology, TDSA LV/1, Milan

Gignac, F.T. 1981: A Grammar of the Greek Papyri of the Roman and Byzantine Periods II: Morphology, TDSA LV/2, Milan

Godlewski, W. 1990: The Cruciform Church at Old Dongola (Sudan). Some Comments, [in:] Godlewski, W. (Ed.), Coptic Studies. Acts of the Third International Congress of Coptic Studies, Warsaw, 20-25 August 1984, Varsovie, 127-137

Godlewski, W. 2006: Pachoras: The Cathedrals of Aetios, Paulos and Petros. The Architecture, PAM Supplement Series 1, Warsaw

Griffith, F.Ll. 1926: Oxford Excavations in Nubia, AAALiv XIII, 17-37, 49-100

Griffith, F.Ll. 1928: Christian Documents from Nubia, PBA XIV, London, 117-146

Jakobielski, S. 1972: A History of the Bishopric of Pachoras on the Basis of Coptic Inscriptions, Faras III, Warszawa

Jakobielski, S. 1974: Inscriptions, [in:] Michałowski, K., Faras: Wall Paintings in the Collection of National Museum at Warsaw, Warsaw, 277-309

Kubińska, J. 1974: Inscriptions grecques chrétiennes, Faras IV, Warszawa

Kubińska, J. 1976: Prothesis de la cathédrale de Faras. Documents et recherches, RAHA 9, 7-37

Łajtar, A. 2003: Wall Inscriptions in the Banganarti Churches: A General Note after Three Seasons of Work, JJP 33, 137-159

Łajtar, A. 2006: Christian Saï in Written Records (inscriptions and manuscripts), JJP 36, 91-104

Łajtar, A. 2008: Banganarti 2006: The Inscriptions, PAM XVIII, 396-402

Łajtar, A. 2010: The Greek of Late Christian Inscriptions from Nubia - The Evidence from Banganarti and Other Sites, [in:] Godlewski, W., Lajtar, A. (Eds), Between the Cataracts. Proceedings of the 11th Conference for Nubian Studies, Warsaw University, 27 August - 2 September 2006. Part II, fascicule 2: Session papers, PAM Supplement Series 2.2/2, Warsaw, 759-763

Łajtar, A. 2014: Archangel Raphael in Inscriptions from the Upper Church at Banganarti, [in:] Żurawski, B. et al., Kings and Pilgrims: St Raphael Church II at Banganarti, Mid-Eleventh to Mid-Eighteenth Century, Nubia V, Banganarti 2, Warszawa, 261-283

Łajtar, A. 2015: The Mystery of Timikleos Solved!, [in:] Łajtar, A., Ochała, G., Vliet, J. van der (Eds), Nubian Voices II. New Texts and Studies in Christian Nubian Culture, JJP-Suppl. XXVII, Warsaw, 231-243

Łajtar, A. forthcoming: A Late Christian Pilgrimage Centre in Banganarti: Evidence of Inscriptions, JJP-Suppl., Warsaw

Łajtar, A., Ochała, G. 2015: Two Wall Inscriptions from the Faras Cathedral with Lists of People and Goods, [in:] Łajtar, A., Ochała, G., Vliet, J. van der (Eds), Nubian 
Voices II. New Texts and Studies on Christian Nubian Culture, JJP-Suppl. XXVII, Warsaw, 73-102

Mina, T. 1942: Inscriptions coptes et grecques de Nubie, Le Caire

Pernigotti, S. 1975: Stele cristiane da Sakinya nel Museo di Torino, OrAnt 14/1, 21-55

P.QasrIbrim II: Browne, G.M., Old Nubian Texts from Qasr Ibrim II, EES Texts from Excavations 10, London 1989

Satzinger, H. 1992: Das altnubische Namenselement -kouda: “Diener"?, [in:] Luft, U. (Ed.), The Intellectual Heritage of Egypt. Studies Presented to László Kákosy by Friends and Colleagues on the Occasion of His 60th Birthday, StudAeg XIV, Budapest, 519-521

Seignobos, R. 2015: Les évêchés nubiens: nouveaux témoignages. La source de la liste de Vansleb et deux autres textes méconnus, [in:] Łajtar, A., Ochała, G., Vliet, J. van der (Eds), Nubian Voices II. New Texts and Studies on Christian Nubian Culture, JJP-Suppl. XXVII, Warsaw, 151-229

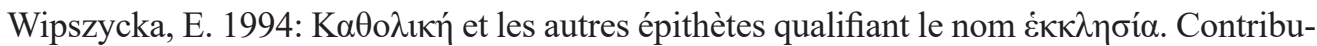
tion à l'étude de l'ordre hiérarchique des églises dans l'Égypte byzantine, JJP XXIV, 191-212 


\section{ÉTUDES et TRAVAUX XXX / 2017}

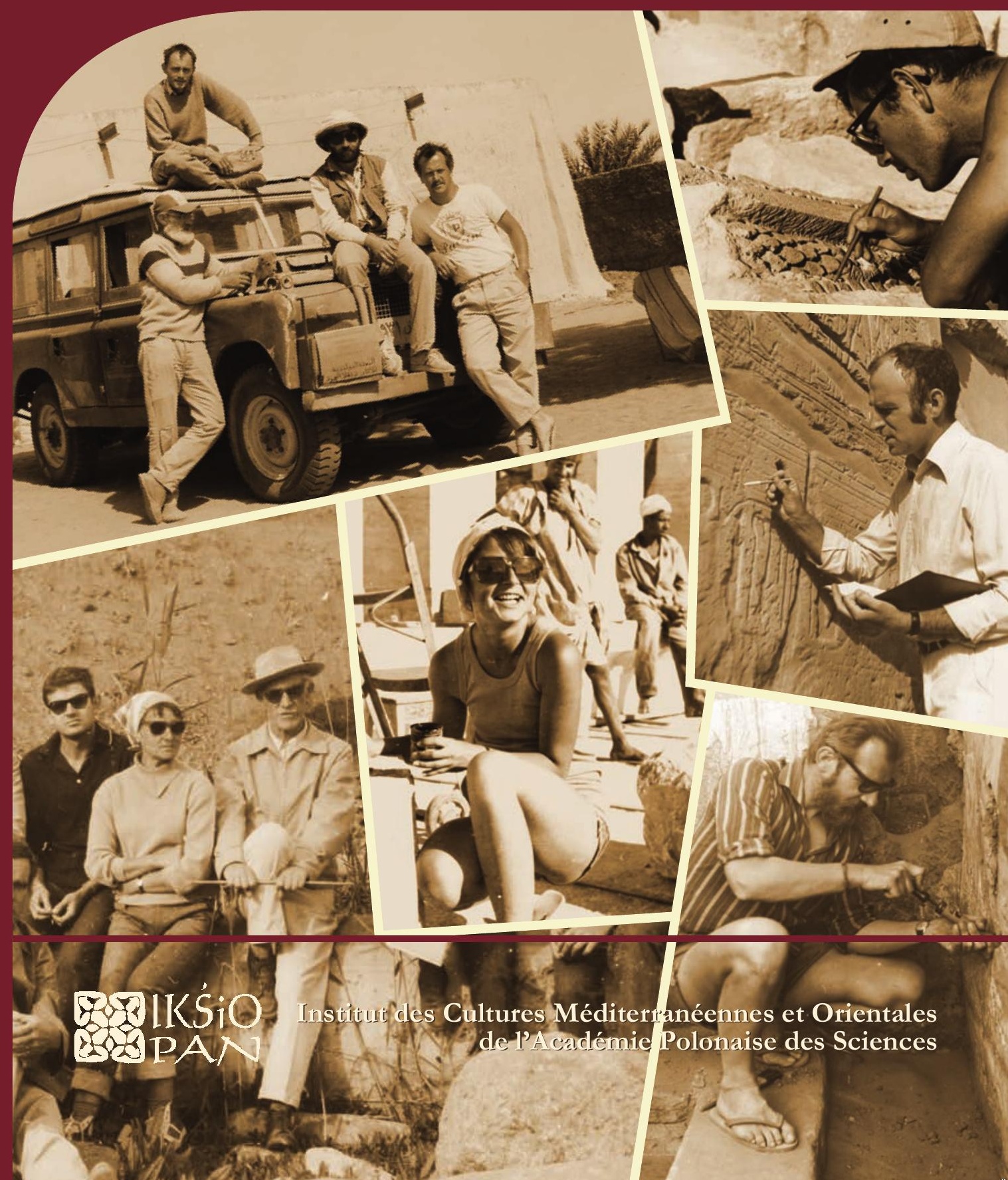




\title{
COMITÉ DE RÉDACTION SCIENTIFIQUE
}

Maciej Makowski - rédacteur en chef

Jadwiga Iwaszczuk - rédacteur et sécretaire de la rédaction

Mariusz Drzewiecki - rédacteur

Maciej G. Witkowski - rédacteur

\section{CONSEIL SCIENTIFIQUE DU JOURNAL}

M. Kobusiewicz (IAE PAS, Warszawa), E. Laskowska-Kusztal (IMOC PAS, Warszawa),

D. Michaelides (University of Cyprus, Nicosia),

J.Ch. Moretti (IRAA-MOM, Université de Lyon 2/CNRS),

D. Raue (Ägyptisches Museum der Universität Leipzig), P. Reynolds (ICREA, Barcelona),

D. Welsby (British Museum, London)

\section{COMITÉ SCIENTIFIQUE DE LECTURE}

J. Holaubek (Institut für Ägyptologie, Wien), S. Ikram (AUC, Cairo),

K. Innemée (Universiteit Leiden), J. McKenzie (Faculty of Oriental Studies, University of Oxford),

N. Strudwick (University of Cambridge), A. Loprieno-Gnirs (Universität Basel),

Ch.E. Loeben (Museen für Kulturgeschichte, Hannover), Y. Tristant (Macquarie University, Sydney),

V.W.J. van Gerven Oei (University of Aberdeen), A. Peignard-Giros (HiSoMA-MOM, Université de Lyon 2/CNRS), J.A. Ostrowski, E. Papuci-Władyka, J. Śliwa (IA JU, Kraków), R. Czerner (WUST, Wrocław), A. Ćwiek (IA AMU, Poznań), M. Wiewióra (IA NCU, Toruń), K. Domżalski

(IAE PAS, Warszawa), K.O. Kuraszkiewicz (DE FOS UW), M. Barwik, P. Bieliński, P. Dyczek, W. Godlewski, D. Ławecka, S. Rzepka, J. Żelazowski, M. Gawlikowski, J. Młynarczyk, A. Niwiński, T. Sarnowski, D. Szeląg, T. Waliszewski (IA UW, Warszawa)

\section{RÉDACTEUR THÉMATIQUE DU VOLUME \\ Barbara Lichocka}

\author{
AIDE RÉDACTION TECHNIQUE \\ Dorota Dobrzyńska, Mariusz Drzewiecki
}

REVUE DES TEXTES ANGLAIS

Jo Harper 
ÉTUDES et TRAVAUX XXX 
INSTYTUT KULTUR ŚRÓDZIEMNOMORSKICH I ORIENTALNYCH POLSKIEJ AKADEMII NAUK

\section{STUDIA i PRACE}

XXX

\section{Ro IKŚSiO \\ ESA PAN}

WARSZAWA

2017 
INSTITUT DES CULTURES MÉDITERRANÉENNES ET ORIENTALES DE L'ACADÉMIE POLONAISE DES SCIENCES

\section{ÉTUDES et TRAVAUX}

XXX

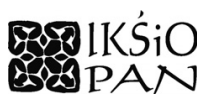

VARSOVIE

2017 
Publication scientifique financée dans le cadre du programme du Ministre de la Science et de l'Éducation Supérieure

« Programme National de Développement de l’Humanistique » pour les années 2016-2021 (projet no 3bH 150099 83)

\title{
HARODOWY PROGRAM ROZWOJU HUMANISTYKI
}

\author{
Copyright (C) \\ Instytut Kultur Śródziemnomorskich i Orientalnych PAN \\ et les Auteurs \\ Warszawa 2017
}

\author{
ISSN 2084-6762 \\ (avant $2011: 0079-3566$ ) \\ e-ISSN 2449-9579 \\ Version première en papier, imprimée en Pologne - 150 copies \\ Version électronique accessible sur \\ http://www.etudesettravaux.iksiopan.pl
}

Édition: Polskie Towarzystwo Historyczne et Wydawnictwo Neriton, Warszawa

Conception générale de couverture : J. Iwaszczuk

Photos de couverture : En haut, à gauche. Vieille Dongola 1991, S. Jakobielski

(debout à gauche), K. Pluskota (debout à droite), B. Żurawski (assis sur le camion)

et P. Wierzbicki (assis sur le camion) (de la collection de B. Żurawski)

En haut, à droite. Palmyre 1964, M. Marciniak au travail (phot. A. Dziewanowski)

Au centre. E. Laskowska-Kusztal au travail (de la collection de E. Laskowska-Kusztal)

En bas, à gauche. Tell Atrib 1962 ; de gauche : T. Biniewski, M. Marciniak, K. Kołodziejczyk,

K. Michałowski, A. Ostrasz, S. Jakobielski et S. Jasiewicz devant eux

(de la collection de IKŚSiO PAN).

En bas, à droite. Vieille Dongola 1976, S. Jakobielski nettoyant le mur (phot. M. Steinborn).

Au centre, à droite, K. Myśliwiec en train des travaux de documentation (de la collection de IKŚiO PAN) 


\section{Table des matières}

BARBARA LICHOCKA

Ergon agathon

Hartwig Altenmüller

$\mathrm{Zu}$ den Feindbildern auf den Zauberstäben des Mittleren Reiches und der Zweiten

Zwischenzeit

Nathalie Beaux

Des $m s w n s w$ de Thoutmosis III à Deir el-Bahari

Briant Bohleke, Nigel Strudwick

A Label for Opening of the Mouth Implements from the Burial of Senneferi (TT99)

and Remarks on the Ritual

Rosa Maria Bonacasa Carra, Nicola Bonacasa

Nuovi dati sugli edifici termali di Sabratha

EDWARD BROVARSKI

A Fragmentary Carrying Chair Scene in Salt Lake City, Utah

Julia Burdajewicz

Wall Painting Decoration from the North-West Church in Hippos-Sussita

of the Decapolis

Mariusz BURDAJEWICZ

From Pagan Temple to Church in Late Antiquity Palestine. A View from

Hippos-Sussita

MAREK ChlodNicki

Early Dynastic Bead Workshops at the Central Kom of Tell el-Farkha.

Patryk ChudziK, Mariusz Caban

Observations on the Architecture of the Tomb of Horhotep in Western Thebes

Krzysztof M. Cialowicz

New Discoveries at Tell el-Farkha and the Beginnings of the Egyptian State.

Amr EL-TiebI

Four Wooden New Kingdom Female Statuettes in the Egyptian Museum, Cairo 


\section{Naguib KanaWATI}

Ritual Marriage Alliances and Consolidation of Power in Middle Egypt during the Middle Kingdom

Adam Łajtar, Jolanta Mlynarczyk

A Faction Acclamation Incised on a Pithos Found Near the North-West Church at Hippos (Sussita)

Adam ŁaJTAR, Grzegorz OchaŁa

Two Private Prayers in Wall Inscriptions in the Faras Cathedral

Adam Łajtar, Anna Poludnikiewicz

Medicinal Vessels from Tell Atrib (Egypt)

JaCeK Michniewicz, Jolanta MlynarczyK

Petrographic Variability of the Fabrics of Wine Jars from Sha'ar-Ha Amakim as a Reflection of Differences in Their Provenance and Chronology

Iwona ModrzewsKa-PianetTI

Les importations d'amphores Dressel 20 en Gaule Cisalpine

Arthur SEgal

Samaria-Sebaste. Portrait of a polis in the Heart of Samaria 409

JOACHIM ŚLIWA

The Motif of a 'Blind Harper' in an Unexpected Place

MONIKA WIĘCH

Searching for the Kitchen in the Early Roman Phase of the 'Hellenistic' House at Nea Paphos (Cyprus)

Abréviations 
THE VOLUME IS PUBLISHED TO CELEBRATE

THE $60^{\text {TH }}$ ANNIVERSARY

OF THE ESTABLISHMENT OF

THE RESEARCH CENTRE FOR MEDITERRANEAN ARCHAEOLOGY POLISH ACADEMY OF SCIENCES

FOUNDED IN 1956

WHOSE MISSION IS CONTINUED BY

THE INSTITUTE OF MEDITERRANEAN AND ORIENTAL CULTURES

OF THE POLISH ACADEMY OF SCIENCES 